Volodymyr MIRNENKO ${ }^{1}$, Valentyn DYPTAN ${ }^{1}$, Serhii PUSTOVYI ${ }^{2}$, Oleg RADKO ${ }^{1}$, Petro YABLONSKYI ${ }^{1}$

${ }^{I}$ National Defense University of Ukraine named after Ivan Chernyakhovsky

${ }^{2}$ Kotris LLC

\title{
OPTIMIZATION OF THE REGULATED MAINTENANCE PERIODICITY ON MILITARY EQUIPMENT PRODUCTS OPERATED ACCORDING TO THEIR TECHNICAL CONDITION
}

\section{Optymalizacja okresowości przeprowadzenia obsługiwania planowego na wyrobach sprzętu wojskowego eksploatowanych według stanu technicznego}

\begin{abstract}
The article is dedicated to the optimization problem of the regulated maintenance periodicity for military products operated according to their technical condition. The analytical method of optimization for the exponential law of the time distribution between failures and the numerical optimization method for the diffusion-monotonic law are taken into consideration. The search for the extreme value of the regulated maintenance periodicity for the diffusionmonotonic distribution law was conducted with the use of the numerical method applying Mathcad 15.0. The dependencies of both the technical utilization factor and its derivative on the regulated maintenance periodicity at certain values of the model parameters were obtained.
\end{abstract}

Keywords: optimization, diffusion-monotonic distribution, type I errors, the utilization factor, numerical method

Streszczenie: $W$ pracy podjęto problem optymalizacji okresowości obstugiwania planowego dla produktów wojskowych eksploatowanych wedtug stanu technicznego. Rozważano analityczna metodę optymalizacji dla wyktadniczego prawa rozkładu czasu między awariami oraz metodę numeryczna optymalizacji dla prawa dyfuzyjno-monotonicznego (za pomoca Mathcada 15.0). Uzyskano zależności zarówno współczynnika wykorzystania technicznego, jak i jego pochodnej od okresowości obstugiwania planowego przy określonych wartościach parametrów modelu.

Słowa kluczowe: optymalizacja, rozkład dyfuzyjno-monotoniczny, błędy pierwszego rodzaju, współczynnik wykorzystania technicznego, metoda numeryczna 


\section{Introduction}

Currently, the optimization issues of the maintenance of both civilian and military equipment products are actively discussed in the scientific and technical literature. This is proved by many publications on this topic $[3-5,7,8]$. The vast majority of works is devoted to the optimization of aircraft maintenance. This is due to high requirements of flight safety and high cost of this equipment. These requirements include, among others, dependability of aircraft engines that significantly affects flight safety [1].

The maintenance efficiency of military products is usually chosen as a maximum criterion of the availability factor $K_{g}$ or of the utilization factor $K_{t v}$, which demonstrate certain interrelations between themselves.

$K_{g}$ or $K_{t v}$ depend on the reliability and maintainability, which are laid at the design stage and provided at the production stage. During the operation of military equipment, it is important to choose the regulated maintenance periodicity, which significantly affects $K_{g}$ and $K_{t v}$. In connection with the above, the scientific novelty of the article is the substantiation of the regulated optimal maintenance periodicity in order to ensure the maximum value of the utilization factor for the operation system of military products according to their technical condition.

Finding the regulated optimal maintenance periodicity that provides maximum availability factor (utilization factor) is considered to be a relevant task. To solve it, you need to know the analytical dependence of the availability factor (utilization factor) on the maintenance parameters. In the presence of such dependence, the most fundamental method of searching for the regulated optimal maintenance periodicity is to take a derivative of $K_{g}\left(K_{t v}\right)$ on the regulated maintenance periodicity. If you equate this derivative to zero, you can find the optimal value of the desired periodicity.

\section{The solution to the problem using the exponential law of time distribution between failures}

In paper [9], an analytical dependence of the utilization factor on the maintenance parameters for the exponential law of time distribution between failures was obtained. A partial derivative $\frac{d K_{t v}}{d T}$ of the utilization factor with respect to the regulated maintenance periodicity for an exponential distribution law with some simple assumptions has the following form: 


$$
\frac{d K_{t v}}{d T}=\frac{\frac{d_{n g}-1}{d_{n g}} \cdot \lambda_{o}+\frac{t_{p r}+t_{p}}{T^{2}}+\left(\frac{\lambda_{p r}}{d_{n g}}-\lambda_{p r}\right) \cdot \lambda_{o} \cdot\left(t_{p r}+t_{p}-d_{n g} \cdot t_{p r}\right)+\frac{1-d_{n g}}{d_{n g}} \cdot \lambda_{p r} \cdot \lambda_{o} \cdot t_{p}}{\left\{1+\frac{1-d_{n g}}{d_{n g}} \cdot \lambda_{o} \cdot T+\left(\frac{1-\lambda_{o} \cdot T}{T}\right) \cdot\left(t_{p r}+t_{p}\right)+\frac{\lambda_{o}}{d_{n g}} \cdot\left(t_{p r}-d_{n g} \cdot t_{p r}+t_{p}\right)+\lambda_{o} \cdot t_{p}\right\}^{2}}
$$

If equation (1) is averaged to zero, it is possible to determine the regulated optimal maintenance periodicity $T_{o p t}$, at which the utilization factor will be maximum:

$$
T_{o p t}=\sqrt{\frac{t_{p r}+t_{p}}{\frac{1-d_{n g}}{d_{n g}} \cdot\left[\lambda_{o} \cdot\left(1-\lambda_{p r} \cdot t_{p}-\lambda_{p r} \cdot\left(t_{p r}+d_{n g} \cdot t_{p r}+t_{p}\right)\right)\right]}}
$$

where:

$T$ - the regulated maintenance periodicity;

$t_{p r}$ - the duration of the missed failure manifestation;

$t_{p}$ - the check-out time of the object of control (OC);

$\lambda_{\mathrm{o}}-$ the failure rate of the $\mathrm{OC}$;

$d_{n g}$ - the reliability of the correct determination of the failure state of the OC.

Equation (2) is analyzed below.

At $d_{n g}=1, T_{\text {opt }} \rightarrow \infty$, for an exponential law of time distribution between failures for an ideal control system, there is no optimal regulated maintenance periodicity, because it is infinite.

Formula (2) is valid for determining the regulated optimal maintenance periodicity for an exponential law of time distribution between failures, provided that the reliability value of the correct determination of the failure state of the OC is less than one. It can be seen from formula (2) that the optimal period is the longer, the longer is the interval between failures of the OC, which corresponds well to physical representations.

If $\lambda_{\mathrm{pr}}=0$, then $T_{\text {opt }}$ will also depend on $t_{p r}, t_{n}, d_{n g}$, and $\lambda_{\mathrm{o}}$.

Obtaining an analytical expression for a regulated optimal maintenance periodicity has become possible for an exponential distribution law, which is quite simple. For more complex distribution laws, which include the diffusion-monotonic distribution law, it is not possible to obtain an analytical expression to determine $T_{\text {opt }}$. Numerical research methods are needed to solve this problem.

The solution to such a problem significantly depends on the complexity of the function $K_{g}\left(K_{t v}\right)$. 


\section{The solution to the problem using the diffusion- -monotonic law of time distribution between failures}

Paper [6] is dedicated to the analytical dependence of the utilization factor on the maintenance parameters of military equipment products operated according to their technical condition taking into account type I errors:

$$
K_{t v}=\frac{\sum_{i=1}^{6} \pi_{i}(T) \cdot \omega_{i}(T)}{\sum_{i=1}^{6} \pi_{i}(T) \cdot \eta_{i}(T)}
$$

Where:

$\pi_{\mathrm{i}}(T)-$ is the frequency of the Markov chain, where $i=\overline{1,6}$;

$\omega_{\mathrm{i}}(T)$ - the time of the OC remaining in perfect state;

$\eta_{i}(T)$ - the time of the OC remaining in any state.

For the proposed model:

$$
\omega_{i}(T)=\omega_{1}(T)=\int_{0}^{T}(1-F(x)) \cdot e^{-\lambda x} d x,
$$

where:

$$
F(x)=\Phi\left(\frac{t-\mu}{v \cdot \sqrt{\mu \cdot t}}\right)[2], \text { and } \Phi(x)=\frac{1}{\sqrt{2 \pi}} \cdot \int_{0}^{x} e^{-\frac{t^{2}}{2}} d t
$$

The components of the frequencies vector of getting Markov chain to the model states are equal to:

$$
\begin{gathered}
\pi_{1}(T)=a(T) \\
\pi_{2}(T)=a(T) \cdot\left[(1-F(T)) \cdot e^{-\lambda T}\right] \\
\pi_{3}(T)=a(T) \cdot\left[(1-\rho) \cdot \int_{0}^{T} e^{-\lambda t} \cdot d F(t)\right]
\end{gathered}
$$




$$
\begin{gathered}
\pi_{4}(T)=a(T) \cdot\left[\begin{array}{l}
(1-\rho) \cdot \int_{0}^{T} e^{-\lambda t} \cdot d F(t)+ \\
+\rho \int_{0}^{T} e^{-\lambda t} \cdot d F(t)+\lambda \int_{0}^{T} e^{-\lambda t}(1-F(t)) d t\left(1-d_{\Gamma}\right)
\end{array}\right] \\
\pi_{5}(T)=a(T) \cdot\left(\rho \int_{0}^{T} e^{-\lambda t} \cdot d F(t)\right) \\
\pi_{6}(T)=a(T) \cdot\left[\lambda \int_{0}^{T} e^{-\lambda t}(1-F(t)) d t\right]
\end{gathered}
$$

where:

$$
a(T)=\frac{1}{1+(1-F(T)) \cdot e^{-\lambda T}+2\left[(1-\rho) \cdot \int_{0}^{T} e^{-\lambda t} \cdot d F(t)\right]+2\left(\rho \int_{0}^{T} e^{-\lambda t} \cdot d F(t)\right)+\lambda \int_{0}^{T} e^{-\lambda t}(1-F(t)) d t\left(2-d_{\Gamma}\right)}
$$

The components of the vector staying time of the $\mathrm{OC}$ in the model states have the following values:

$$
\begin{aligned}
& \eta_{1}(T)=(1-F(T)) \cdot e^{-\lambda T}+(1-\rho) \cdot \int_{0}^{T} e^{-\lambda t} \cdot d F(t) \cdot T+\rho \int_{0}^{T} e^{-\lambda t} \cdot d F(t) \cdot \int_{0}^{T} t \cdot d F_{15}(t)+ \\
& +\lambda \int_{0}^{T} e^{-\lambda t}(1-F(t)) d t \cdot \int_{0}^{T} t \cdot d F_{16}(t)
\end{aligned}
$$

Where:

$$
\begin{gathered}
F_{15}(T)=\frac{\int_{0}^{t} e^{-\lambda x} \cdot d F(x)}{\int_{0}^{T} e^{-\lambda x} \cdot d F(x)} ; \\
F_{16}(T)=\frac{\int_{0}^{t} e^{-\lambda x} \cdot(1-F(x)) d x}{\int_{0}^{T} e^{-\lambda x} \cdot(1-F(x)) d x} ;
\end{gathered}
$$




$$
\eta_{2}(T)=6.5 \mathrm{~h} ; \eta_{3}(T)=2.5 \mathrm{~h} ; \eta_{4}(T)=5 \mathrm{~h} ; \eta_{5}(T)=\eta_{6}(T)=1 \mathrm{~h}
$$

In formulas (4) - (16), the following notations are used:

$F(x)$ - the distribution function of the diffusion-monotonic distribution;

$\Phi(x)$ - the Laplace function;

$\lambda(t)$ - the intensity of receiving false alarms about failures;

$\rho \quad-$ the probability of receiving information about the failure from the built-in control system;

$\mu \quad$ - the scale parameter of the diffusion-monotonic distribution law;

$v \quad$ - the shape parameter of the diffusion-monotonic distribution law;

$d_{g} \quad$ - reliability of determining the perfect state of the OC;

$T \quad$ - the regulated maintenance periodicity.

The mathematical fault model of such products is the diffusion-monotonic distribution, which is considered as the most modern among the known distribution laws.

A significant disadvantage of such a law is its relative complexity, which significantly complicates its practical use.

\section{Obtaining the results of calculations by numerical method}

Taking a derivative of $K_{t v}$ with respect to the regulated maintenance periodicity $T$ for diffusion-monotonic distribution is a task, which is too difficult. For this reason, this problem is solved in the present manuscript by a numerical method with the use of Mathcad 15.0 program (C Parametric Technology Corporation). The results of solving this problem are shown in figs. $1-7$. 


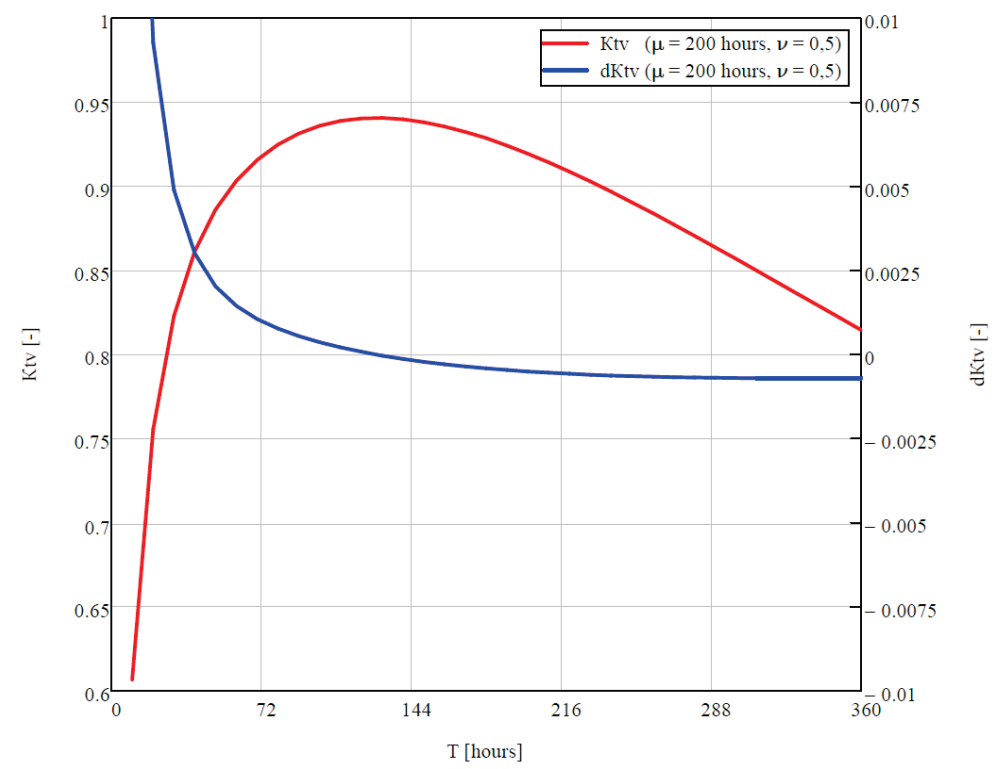

Fig. 1. The dependence of $K_{t v}$ and $\frac{d K_{t v}}{d T}$ on the regulated maintenance periodicity $T$ at the value of the scale factor $\mu=200 \mathrm{~h}$ and the shape factor $v=0.5$

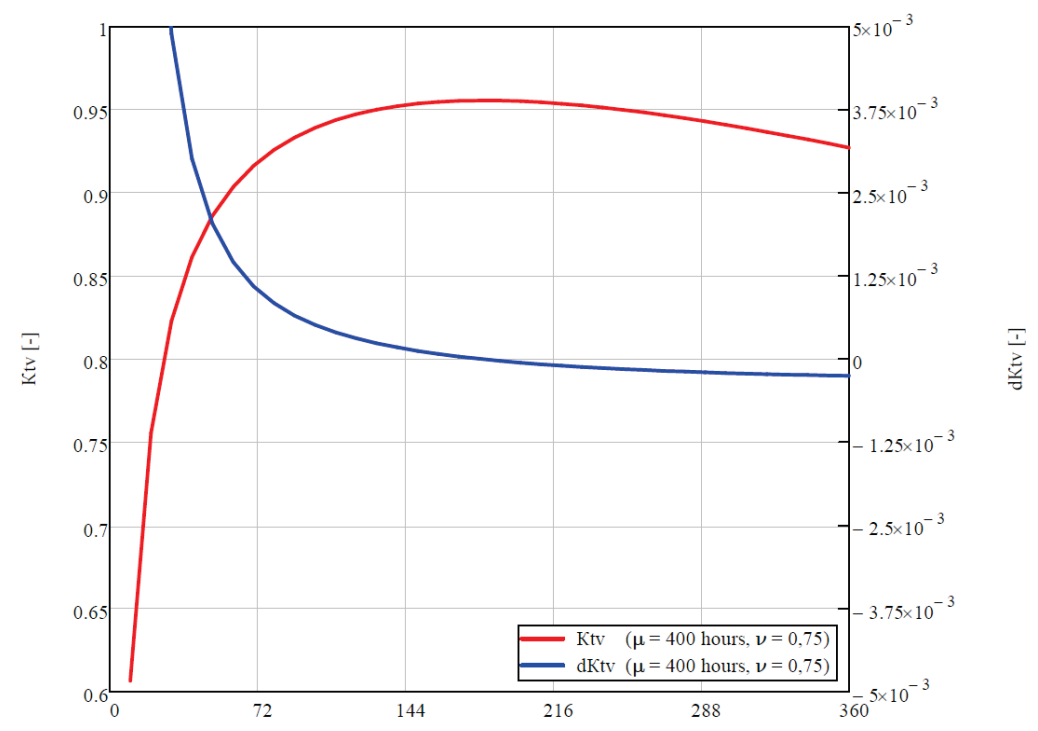

Fig. 2. The dependence of $K_{t v}$ and $\frac{d K_{t v}}{d T}$ on the regulated maintenance periodicity $T$ at the value of the scale factor $\mu=400 \mathrm{~h}$ and the shape factor $v=0.75$ 


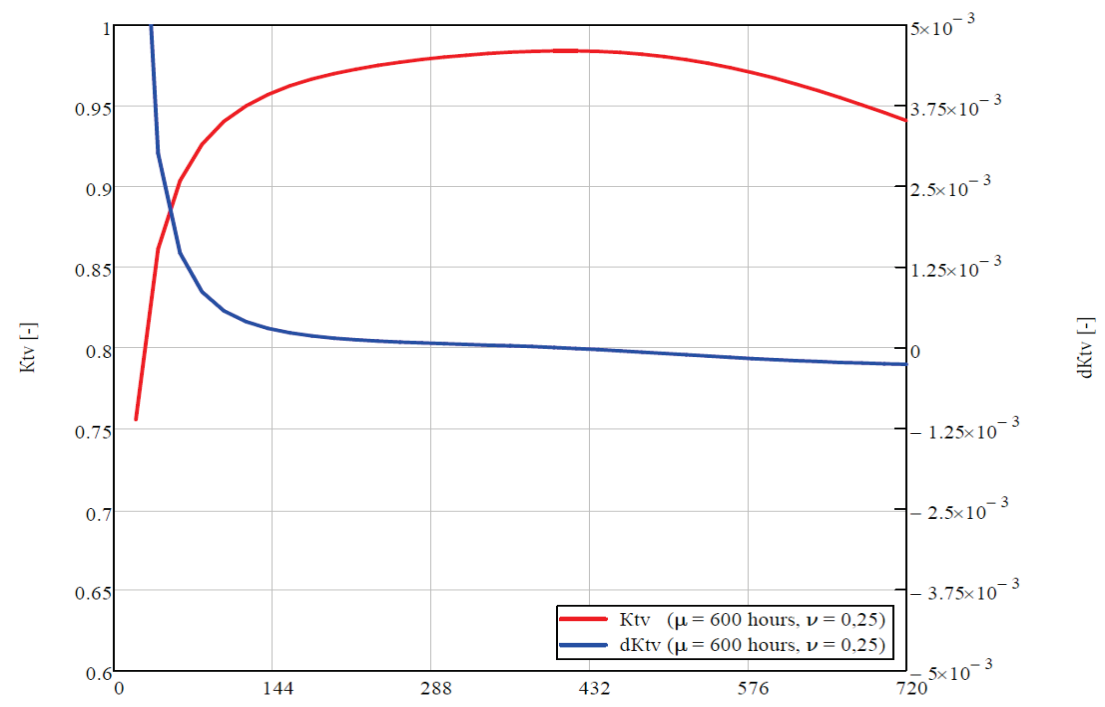

Fig. 3. The dependence of $K_{t v}$ and $\frac{d K_{t v}}{d T}$ on the regulated maintenance periodicity $T$ at the value of the scale factor $\mu=600 \mathrm{~h}$ and the shape factor $v=0.25$

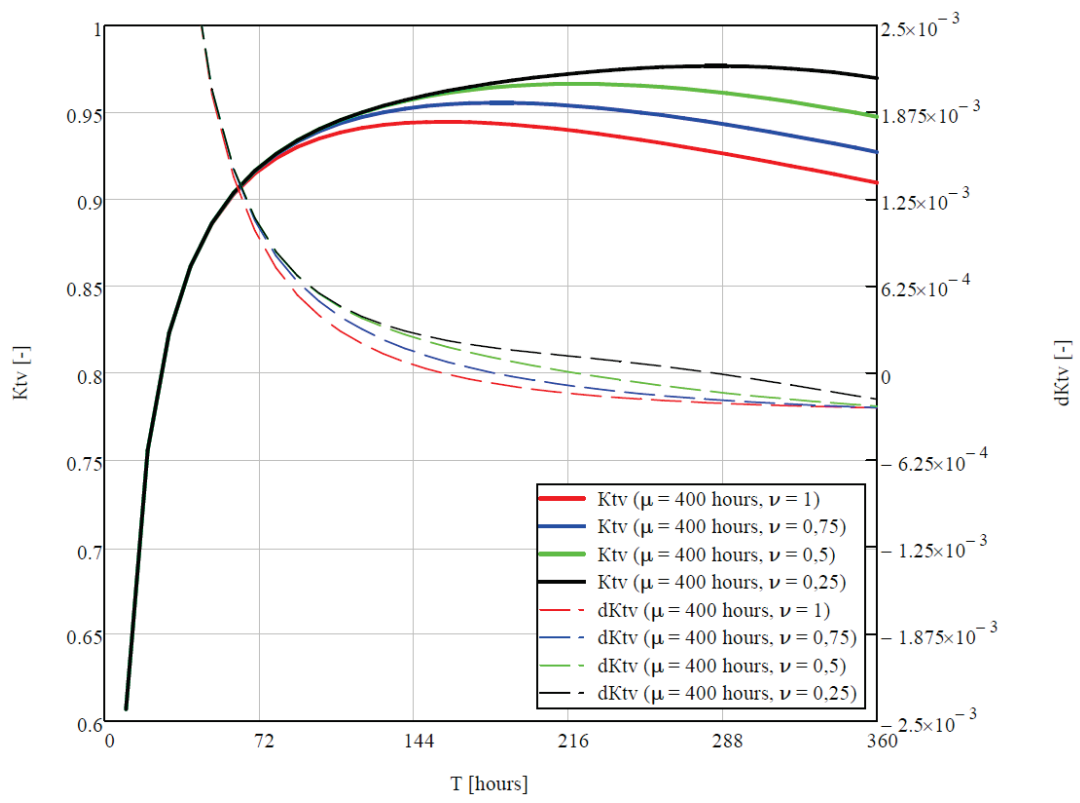

Fig. 4. The dependence of $K_{t v}$ and $\frac{d K_{t v}}{d T}$ on the regulated maintenance periodicity $T$ at the value of the scale factor $\mu=400 \mathrm{~h}$ and varying values of the shape factor $v=1, v=0.75, v=0.5$, $v=0.25$ 


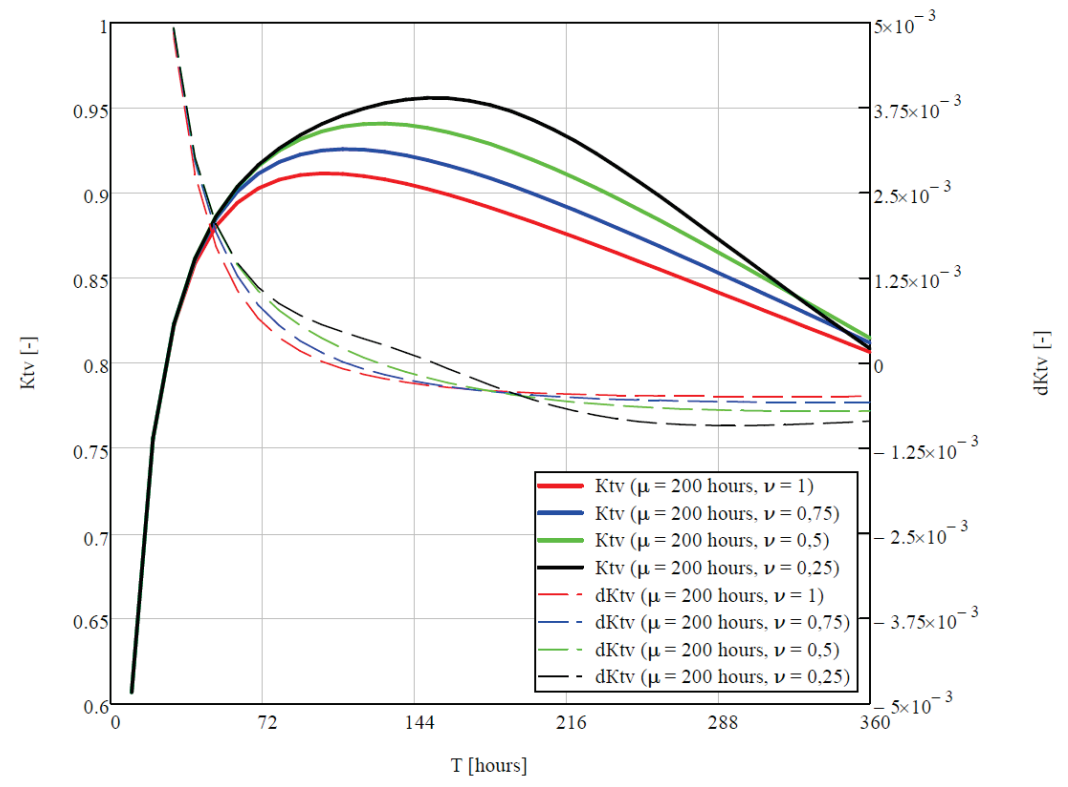

Fig. 5. The dependence of $K_{t v}$ and $\frac{d K_{t v}}{d T}$ on the regulated maintenance periodicity $T$ at the value of the scale factor $\mu=200 \mathrm{~h}$ and varying values of the shape factor $v=1, v=0.75, v=0.5$, $v=0.25$

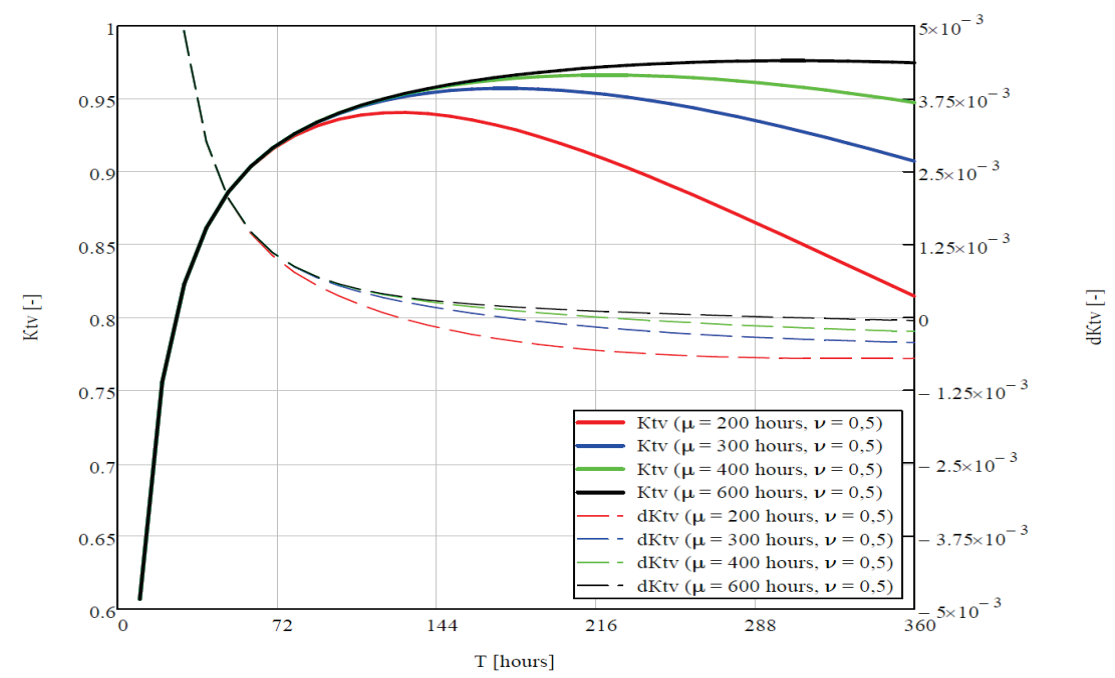

Fig. 6. The dependence of $K_{t v}$ and $\frac{d K_{t v}}{d T}$ on the regulated maintenance periodicity $T$ at varying values of the scale factor $\mu=200 \mathrm{~h}, \mu=300 \mathrm{~h}, \mu=400 \mathrm{~h}, \mu=600 \mathrm{~h}$ and the value of the shape factor $v=0.5$ 


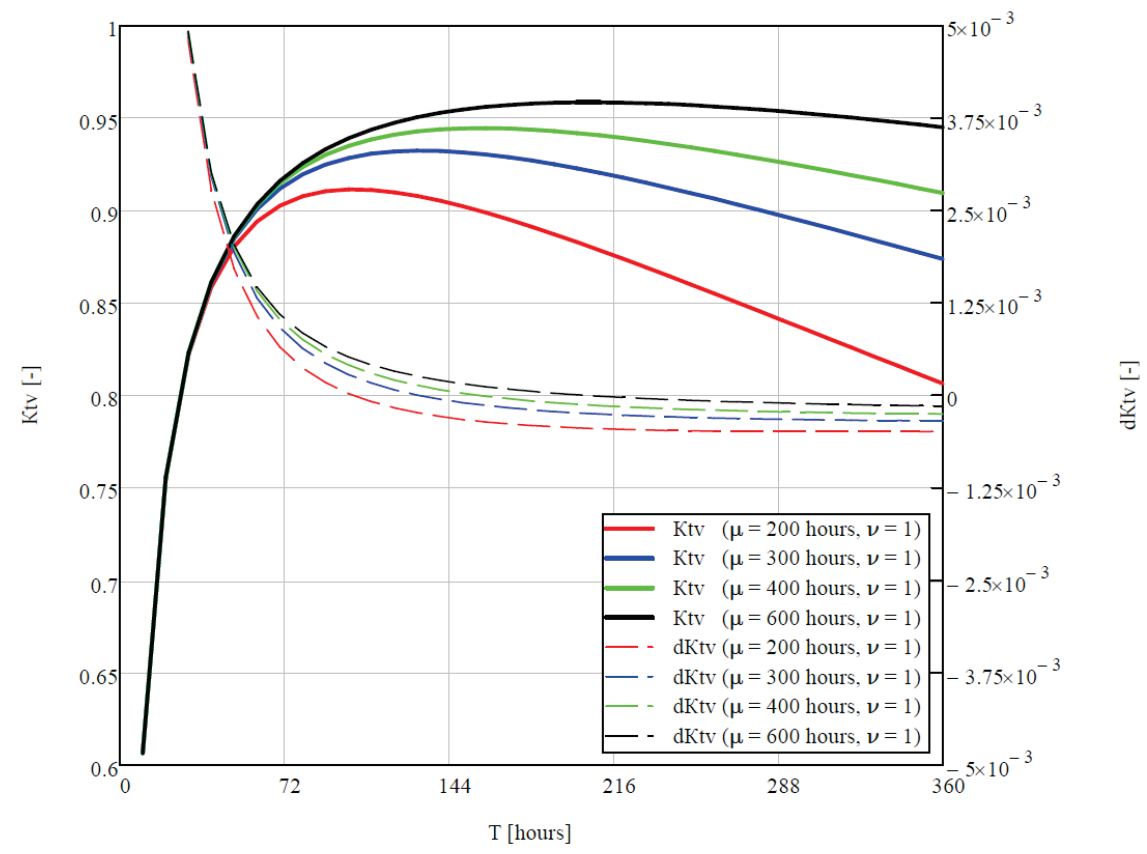

Fig. 7. The dependence of $K_{t v}$ and $\frac{d K_{t v}}{d T}$ on the regulated maintenance periodicity $T$ at varying values of the scale factor $\mu=200 \mathrm{~h}, \mu=300 \mathrm{~h}, \mu=400 \mathrm{~h}, \mu=600 \mathrm{~h}$ and the value of the shape factor $v=1$

\section{The analysis of the graphic dependencies}

For all calculations, the results of which are shown in fig. 1-7 and table 1, the constant values are: $\lambda=10^{-3} 1 / \mathrm{h}, t_{p}=2.5 \mathrm{~h}, t_{p}{ }^{*}=1 \mathrm{~h}, t_{p r}=4 \mathrm{~h}, t_{v}=5 \mathrm{~h}, \rho=0.7$.

To better comprehend the obtained results, the figures are placed in the order from simple to complex. Thus, fig. 1 shows the dependencies of $K_{t v}$ and $\frac{d K_{t v}}{d T}$ on the regulated maintenance periodicity $T$. The left ordinate presents the values of $K_{t v}$, and the right $-\frac{d K_{t v}}{d T}$ values. Calculations were performed for both curves for the values of the scale factor $\mu=200 \mathrm{~h}$ and the shape factor $v=0.5$. Figure 1 shows that when the derivative $\frac{d K_{t v}}{d T}$ is zero, the $K_{t v}$ curve reaches its maximum value. Thus, at constant values of the parameters specified above, $T_{o p t}=127 \mathrm{~h}$, and the maximum value of $K_{t v}=0.941$. 
Table 1

\section{Values of the utilization factor maximum and regulated optimal maintenance periodicity}

\begin{tabular}{|c|c|c|c|}
\hline Fig. № & $\begin{array}{l}\text { Values of the scale } \mu \\
\text { and form } v \text { factors }\end{array}$ & $\begin{array}{l}\text { Maximum value of the } \\
K_{t v}\end{array}$ & $\begin{array}{l}\text { Optimal regulated } \\
\text { maintenance } \\
\text { periodicity, } T_{\text {opt }}, \mathrm{h}\end{array}$ \\
\hline Fig. 1 & $\mu=200 \mathrm{~h}, \nu=0.5$ & 0.941 & 127 \\
\hline Fig. 2 & $\mu=400 \mathrm{~h}, v=0.75$ & 0.956 & 182 \\
\hline Fig. 3 & $\mu=600 \mathrm{~h}, v=0.25$ & 0.984 & 410 \\
\hline \multirow[t]{4}{*}{ Fig. 4} & $\mu=400 \mathrm{~h}, v=0.25$ & 0.977 & 284.62 \\
\hline & $\mu=400 \mathrm{~h}, v=0.5$ & 0.967 & 220 \\
\hline & $\mu=400 \mathrm{~h}, v=0.75$ & 0.956 & 182 \\
\hline & $\mu=400 \mathrm{~h}, v=1$ & 0.945 & 158 \\
\hline \multirow[t]{4}{*}{ Fig. 5} & $\mu=200 \mathrm{~h}, v=0.25$ & 0.956 & 153.5 \\
\hline & $\mu=200 \mathrm{~h}, v=0.5$ & 0.941 & 127 \\
\hline & $\mu=200 \mathrm{~h}, v=0.75$ & 0.923 & 111.8 \\
\hline & $\mu=200 \mathrm{~h}, v=1$ & 0.911 & 102 \\
\hline \multirow[t]{4}{*}{ Fig. 6} & $\mu=200 \mathrm{~h}, v=0.5$ & 0.941 & 127 \\
\hline & $\mu=300 \mathrm{~h}, v=0.5$ & 0.957 & 175 \\
\hline & $\mu=400 \mathrm{~h}, v=0.5$ & 0.967 & 220 \\
\hline & $\mu=600 \mathrm{~h}, v=0.5$ & 0.976 & 305 \\
\hline \multirow[t]{4}{*}{ Fig. 7} & $\mu=200 \mathrm{~h}, \nu=1$ & 0.912 & 102 \\
\hline & $\mu=300 \mathrm{~h}, v=1$ & 0.933 & 131 \\
\hline & $\mu=400 \mathrm{~h}, v=1$ & 0.945 & 158 \\
\hline & $\mu=600 \mathrm{~h}, v=1$ & 0.959 & 206 \\
\hline
\end{tabular}

Figure 2 shows that when increasing the scale parameter to $\mu=400 \mathrm{~h}$, which is equivalent to increasing the product dependability, and the value of $v=0.75, T_{\text {opt }}=182 \mathrm{~h}$, and the maximum value of $K_{t v}=0.956$.

With a further increase of the scale parameter to $\mu=600 \mathrm{~h}$ and $v=0.25, T_{\text {opt }}=410 \mathrm{~h}$, and the maximum value of $K_{t v}=0.984$. The optimal result corresponds well to physical considerations (fig. 3).

Figures 4-7 show four curves for $K_{t v}$ and $\frac{d K_{t v}}{d T}$ accordingly.

Figure 4 shows similar dependencies at $\mu=400 \mathrm{~h}$ and varying values of the shape factor $v$. 
Figure 5 shows that for all curves, the scale parameter is equal to $\mu=200 \mathrm{~h}$, and the shape parameter increases from $v=0.25$ to $v=1$. When each derivative curve crosses the zero line, the utilization factor reaches its maximum and the scale factor is larger.

Figure 6 illustrates that for all curves, both $K_{t v}$ and $\frac{d K_{t v}}{d T}$ the shape parameter $v=0.5$, and the scale parameter varies from $\mu=200 \mathrm{~h}$ to $\mu=600 \mathrm{~h}$.

The difference between the curves in fig. 7, that for them $v=1$, and the scale parameter varies from $\mu=200 \mathrm{~h}$ to $\mu=600 \mathrm{~h}$. When the shape parameter $v$ is increased from 0.5 to $v=1$, the utilization factor decreases, which is well explained for physical reasons.

The numerical calculations performed in the work using the program Mathcad 15.0 allow establishing with high accuracy the optimal values of the regulated maintenance periodicity, at which the maximum value of the utilization factor is achieved, which is of great practical importance. The calculations show how the maximum values of $K_{t v}$ are affected by the scale and the shape parameter. The results of the calculations are obtained for one of the most complex distribution laws and can be applied for practical use.

\section{Conclusions}

This manuscript solves the problem of the optimization of the regulated maintenance periodicity by the criterion of the maximum of the utilization factor for the military equipment products operated according to their technical condition taking into account type I errors.

The diffusion-monotonic distribution, which is inherent in mechanical type products, is taken as a fault model.

Taking into account the complexity of the dependence of the utilization factor on the parameters of the mathematical model, the optimization problem is solved numerically using the Mathcad 15.0 program for the diffusion-monotonic distribution law.

In the case of the maintenance model, which involves type I and type II errors for the exponential distribution law, the analytical dependence of the (by the criterion of the utilization factor maximum) regulated optimal maintenance periodicity on the model parameters is obtained. The analytical method of the regulated maintenance periodicity optimization has a significant advantage over the numerical method due to the fact that it allows for relatively easy calculations, for example, using formula (2), when changing its components. The advantage of the numerical method in comparison with the analytical method is the ability to establish the optimal period for complex distribution functions, for example, for diffusion-monotonic distribution, when using the analytical method is impossible.

In the future, it is planned to show the impact of the regulated maintenance periodicity on the cost of achieving the maximum value of the utilization factor. 


\section{References}

1. Dmytriiev S.O., Burlakov V.I, Popov O.V., Popov D.V.: Formuvannia prohram tekhnichnoho obsluhovuvannia aviatsiinykh dvyhuniv. Avyatsyonno-kosmycheskaia tekhnyka y tekhnolohyia, No. 7 (104), 2013.

2. DSTU 2862-94 Nadiinist tekhniki. Metody rozrakhunku pokaznykiv nadiinosti. Derzhstandart Ukrainy. Kyiv 1994.

3. Faynburg I.A.: Vyibor i optimizatsiya rezhimov podderzhaniya letnoy godnosti letatelnyih apparatov. NauchnIy vestnik MGTU GA. Seriya Aeromehanika i prochnost, No. 119, 2007.

4. Goncharenko A.: Aeronautical Engineering Maintenance Periodicity Optimization with the Help of Subjective Preferences Distributions. Proceedings of the National Aviation University, No. 2 (71), 2017, DOI 10.18372/2306-1472.71.11746.

5. Khramchenko V.A., Yerko V.B.: Shchodo optymizatsii rezhymiv tekhnichnoho obsluhovuvannia vyrobiv bortovoho obladnannia viiskovoi aviatsiinoi tekhniky. Zb. naukovykh prats DNDIA. Vyp. 13(20), 2016.

6. Mirnenko V., Pustovyi S., Radko O., Yablonskyi P.: Mathematical model of military equipment products maintenance for the condition-based operation strategy taking into account type I errors. Journal of KONBiN, Vol. 50, Issue 1, 2020, DOI 10.2478/jok-2020-0016.

7. Popov D.V.: Optymizatsiia rezhymiv tekhnichnoho obsluhovuvannia aviatsiinoi tekhniky. Visnyk dvyhunobuduvannia. Tekhnolohiia vyrobnytstva i remontu. Zaporizhzhia, No. 2, 2009.

8. Tamarhazin O.A.: Alhorytm umovnoi optymizatsii parametriv systemy tekhnichnoho obsluhovuvannia i remontu aviatsiinoi tekhniky, 2001.

9. Yablonskij P.M., Pustovoj S.A., Open'ko P.V.: Ekonomiko-matematicheskaya model tekhnicheskogo obsluzhivaniya obrazcov vooruzheniya i voennoj tekhniki po sostoyaniyu dlya diffuzionno-nemonotonnogo raspredeleniya otkazov. Ekonomika i predprinimatelstvo, No. 8 (37), 2013. 